\title{
Lamivudine for the treatment of membranous glomerulopathy secondary to chronic hepatitis B infection
}

\author{
SI Gan MD FRCPC ${ }^{1}$, SM Devlin MD FRCPC ${ }^{1}$, NW Scott-Douglas MD FRCPC ${ }^{2}$, KW Burak MD FRCPC ${ }^{1,3}$
}

SI Gan, SM Devlin, NW Scott-Douglas, KW Burak. Lamivudine for the treatment of membranous glomerulopathy secondary to chronic hepatitis B infection. Can J Gastroenterol $2005 ; 19(10): 625-629$.

\begin{abstract}
Membranous glomerulopathy is a well-recognized extrahepatic manifestation of chronic hepatitis B virus (HBV) infection. The authors report two cases of HBV-related nephrotic syndrome treated with lamivudine. A 46-year-old Chinese man had a hepatitis B e antigen seroconversion along with improvement in his nephrotic syndrome after lamivudine therapy. Two years after treatment was discontinued, a reactivation of $\mathrm{HBV}$ was successfully treated again with lamivudine. A 44-year-old Chinese woman, who was intolerant of interferon, was treated with lamivudine for 15 months without a virological response. However, two years after completing lamivudine, her nephrotic syndrome resolved. Implications for the treatment of HBVrelated glomerulopathy and a review of the literature are presented.
\end{abstract}

Key Words: Antiviral therapy; Hepatitis B; Nephrotic syndrome

\section{Lamivudine pour le traitement de la gloméru- lopathie membraneuse secondaire à une hépatite $\mathrm{B}$ chronique}

\begin{abstract}
La glomérulopathie membraneuse est une manifestation extra-hépatique bien connue de l'hépatite $\mathrm{B}$ chronique (causée par le virus de l'hépatite $\mathrm{B}$ ou HBV). Les auteurs font état de deux cas de syndrome néphrotique liés au HBV qui ont été traités par lamivudine. Un homme d'origine chinoise de 46 ans a présenté une séroconversion à l'antigène e de l'hépatite $B$ (HBeAG) et son syndrome néphrotique s'est amélioré après qu'il ait reçu de la lamivudine. Deux ans après l'arrêt du traitement, la réactivation du HBV a été traitée de nouveau avec succès au moyen de lamivudine. Une femme d'origine chinoise de 44 ans qui s'est révélée intolérante à l'interféron a été traitée au moyen de lamivudine pendant 15 mois, sans réponse virologique. Par contre, deux ans après avoir terminé la lamivudine, son syndrome néphrotique est rentré dans l'ordre. Les implications de ces observations pour le traitement de la glomérulopathie liée au HBV sont présentées ici avec une revue de la littérature.
\end{abstract}

M embranous glomerulopathy (MGN) is a well-recognized extrahepatic manifestation of chronic infection with the hepatitis B virus (HBV). The pathogenesis of this association is unclear, but immune complex deposition has been implicated. Therapy of HBV-associated MGN has traditionally involved corticosteroids or interferon with variable degrees of success. There are two reported cases of successful treatment of nephrotic syndrome due to HBV-associated MGN with lamivudine in children $(1,2)$. There is only one case reporting the use of lamivudine in treating HBV-associated MGN in adults, but this patient was also treated with intravenous methylprednisolone and cyclophosphamide (3).

\section{Case 1}

\section{CASE PRESENTATIONS}

A 46-year-old Chinese man, known to be a chronic HBV carrier, presented in March 1999 with peripheral edema and abdominal swelling. His serum albumin was $13 \mathrm{~g} / \mathrm{L}$ and a $24 \mathrm{~h}$ urine collection revealed $7.1 \mathrm{~g}$ /day of proteinuria. He was hypertensive and had hypercholesterolemia (total cholesterol $6.94 \mathrm{mmol} / \mathrm{L}$ ), in keeping with nephrotic syndrome. The serum creatinine was normal. His alanine aminotransferase (ALT) and aspartate aminotransferase (AST) were both noted to be elevated at two times the upper limit of normal (ULN). An abdominal ultrasound revealed a $2 \mathrm{~cm}$ hypoechoic nodule in the left lobe of the liver. An ultrasound-guided biopsy revealed cirrhosis with mild periportal inflammation. There was no evidence of hepatocellular carcinoma and the serum alpha fetoprotein was normal. The hepatitis B surface antigen ( $\mathrm{HBs} A g)$ and hepatitis B e antigen $(\mathrm{HBeAg})$ were both positive. Hepatitis $\mathrm{C}$ serology was negative and other investigations including iron studies, ceruloplasmin, antinuclear antibody, immunogloubulins and alpha-1-antitrypsin were normal. Antineutrophil cytoplasmic antibodies, antinuclear antibody, antiglomerular basement membrane antibodies, syphilis and HIV serology were all negative. The urine and serum protein electrophoresis only revealed findings consistent with nephrotic syndrome. Complement and cryoglobulin levels were not measured. The patient was assessed by the nephrology service and, with negative investigations for other causes of nephrotic syndrome (malignancy, nonsteroidal anti-inflammatory drugs, systemic lupus, rheumatoid arthritis, sarcoidosis, Sjogren's syndrome and schistosomiasis), the patient was thought to have MGN associated with HBV. A renal biopsy was not performed. The patient was started on lamivudine $100 \mathrm{mg} /$ day in May 1999 along with enalapril $20 \mathrm{mg}$ twice daily and diuretic therapy.

\footnotetext{
${ }^{1}$ Divisions of Gastroenterology and ${ }^{2}$ Nephrology; ${ }^{3}$ Liver Unit, Department of Medicine, University of Calgary, Calgary, Alberta

Correspondence: Dr Kelly W Burak, The University of Calgary Medical Clinic, Room G128 Health Sciences Centre, University of Calgary, 3330 Hospital Drive Northwest, Calgary, Alberta T2N 4N1. Telephone 403-210-9363, fax 403-210-9368,

e-mail kwburak@ucalgary.ca
} 


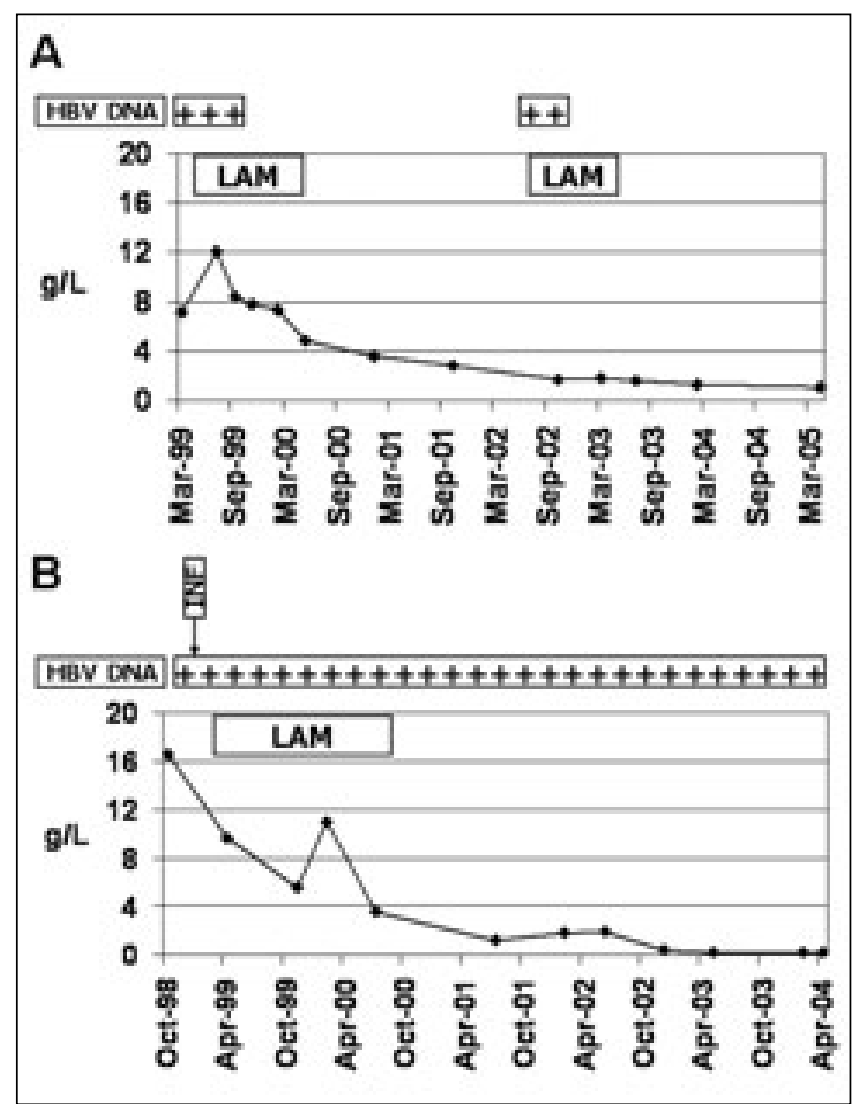

Figure 1) The relationship of $24 \mathrm{~h}$ urine protein excretion $(g / L)$ and hepatitis B virus (HBV) DNA to the use of lamivudine (LAM) in case 1 (A) and case 2 (B). Case 2 received five doses of standard interferon (INF)-alpha $2 b$

By July 1999, the transaminases had normalized; there was marked improvement in the patient's ascites and peripheral edema, allowing for discontinuation of the diuretics. $\mathrm{HBeAg}$ seroconversion was documented after five months of therapy (HBeAg-negative, anti-HBe-positive, HBV DNA-negative). Lamivudine was continued for a total of 12 months. At the end of 12 months, the albumin had increased to $30 \mathrm{~g} / \mathrm{L}$, cholesterol had decreased to $5.43 \mathrm{mmol} / \mathrm{L}$ and the level of proteinuria had decreased to $4.83 \mathrm{~g} /$ day. The patient was maintained on angiotensin-converting enzyme (ACE) inhibitors, and six months later the proteinuria improved to $1.41 \mathrm{~g} /$ day. Twelve months after stopping lamivudine, the serum albumin and cholesterol normalized, although the $24 \mathrm{~h}$ protein excretion was still elevated at $3.5 \mathrm{~g} /$ day.

In June 2002, the serum ALT rose to three times ULN. $\mathrm{HBeAg}$ remained negative, but HBV DNA was detected at a level of $9.4 \mathrm{pg} / \mathrm{mL}$ (Hybrid Capture 2, Digene Corporation, USA). The patient was asymptomatic and there was no evidence of decompensated liver disease. In July 2002, he was restarted on lamivudine $100 \mathrm{mg} /$ day and within three months his ALT normalized and HBV DNA became undetectable. Lamivudine was discontinued after nine months but he remains on ACE inhibitors. He remains well with normal ALT, creatinine, albumin and cholesterol and only has mild proteinuria at $1.23 \mathrm{~g} /$ day as of February 2004. The timeline of lamivudine therapy in relation to the $24 \mathrm{~h}$ urine protein excretion in this case is shown in Figure 1A.
Case 2

A 44-year-old Chinese woman, who was known to be a HBV carrier, presented in October 1998 with ankle edema. Subsequent investigations revealed nephrotic range proteinuria (16.6 g/day), microscopic hematuria with dysmorphic red blood cells, hypercholesterolemia $(14.7 \mathrm{mmol} / \mathrm{L})$ and significant hypoalbuminemia (15 g/L). The serum creatinine was normal. A renal biopsy revealed changes consistent with membranous glomerulonephritis. The patient was started on diuretic therapy and pravastatin. Due to the patient's low blood pressure, ACE inhibitors were never introduced. Further investigations revealed a normal ALT, a positive $\mathrm{HBs} A g$ and positive HBeAg. HBV DNA was present at a level of $5.1 \mathrm{pg} / \mathrm{mL}$ (Abbot assay, Abbott Laboratories, USA). Although she had a normal ALT level, a trial of antiviral therapy was undertaken in an attempt to improve the MGN. Interferon-alpha 2b, 10 million units three times weekly, was initiated but was discontinued after only five doses due to significant flu-like symptoms and fatigue. Lamivudine was then started at a dosage of $100 \mathrm{mg} /$ day in March 1999. At this time, the serum ALT was normal and AST was 1.5 times the ULN. When lamivudine was initiated, a $24 \mathrm{~h}$ urine collection revealed $8.2 \mathrm{~g}$ of proteinuria per day, serum albumin was $13 \mathrm{~g} / \mathrm{L}$ and total cholesterol was $11.1 \mathrm{mmol} / \mathrm{L}$. After $12 \mathrm{months}$ of lamivudine therapy, the patient remained $\mathrm{HBeAg}$-positive with an HBV DNA level of $9.36 \mathrm{pg} / \mathrm{mL}$ (Hybrid Capture 2, Digene Corporation, USA). In June 2000, lamivudine was stopped after 15 months due to lack of virological response. The ALT remained normal, and the AST was still 1.5 times the ULN. Her albumin had increased to $18 \mathrm{~g} / \mathrm{L}$ and nephrotic range proteinuria persisted (3.51 g/day). Over the next four years, with no further intervention, there was improvement of her nephrotic syndrome with normalization of her cholesterol and resolution of her peripheral edema. By April 2002, the degree of proteinuria had decreased to $1.82 \mathrm{~g} /$ day and by January 2003 it had further decreased to $0.37 \mathrm{~g} /$ day. More recently, in February 2004, she only had mild proteinuria ( $0.22 \mathrm{~g} /$ day $)$. Despite the improvement in her nephrotic syndrome, she remains HBeAg-positive with detectable HBV DNA (greater than 200,000 copies/mL with the Cobas Amplicor PCR assay, Roche Diagnostics, USA) as of February 2005. Figure 1B illustrates the 24 h urine protein excretion in relationship to the use of interferon and lamivudine in this case.

\section{DISCUSSION}

HBV has long been known to be associated with a variety of glomerular diseases including membranous glomerulonephritis, membranoproliferative glomerulonephritis and mesangial proliferative glomerulonephritis (4-9). In addition, polyarteritis nodosa and immunoglobulin A nephropathy have also been associated with chronic HBV infection (10-13). First described in 1971 by Combes et al (4), MGN is the most commonly associated renal disorder, with epidemiological studies subsequently confirming its association with HBV. Serum positivity for $\mathrm{HBsAg}$ is seen in nearly all cases of MGN in Asia and Africa where there is a high prevalence of chronic HBV, but HBsAg is found in only 20\% to $64 \%$ of MGN cases in countries that have low prevalence of chronic HBV (14-19). The disease can occur at any age but usually presents by the fourth decade. Both pediatric and adult series have been presented and a striking male predominance (in up to $80 \%$ ) has been noted in both age groups $(16,20)$. 
The etiology of HBV-related MGN remains unclear. Postulated to be a disease caused by immune complex deposition, early investigation focused on the three major hepatitis B antigens: surface, core and the ' $e$ ' antigen. There is debate about which of the three major antigens is responsible for the immune response. Initial studies used immunofluorescent staining to demonstrate the presence of all three antigens within glomerular deposits but these results were not confirmed in other studies $(4,5,21)$. A study by Maggiore et al (22) casts doubt on the validity of the immunoglobulin tests used in some studies. Furthermore, other studies have failed to demonstrate localization of preformed immune complexes in the glomerular subepithelium. Similarly, circulating immune complexes of hepatitis $B$ antigens have been detected in some but not all studies (23-25). HBV DNA has also been isolated in the glomerulus and the proximal tubules of MGN patients, but the actual significance of this is unknown $(26,27)$.

The natural history of HBV-related glomerulopathy has been collected from case series in both children and adults. Wong et al (20) retrospectively identified 18 pediatric cases in Hong Kong, in which $78 \%$ of children presented with nephrotic syndrome. Four patients presented with gross hematuria and proteinuria and three of these patients subsequently developed nephrotic syndrome some time later. Albumin and cholesterol levels were usually consistent with nephrotic syndrome. Five patients received no treatment, 11 received steroids and two received interferon. Within three years of diagnosis, $10(59 \%)$ patients had complete and persistent remission. Of the untreated patients, only one achieved remission and the remaining patients had persistent proteinuria, chronic renal failure or end-stage renal failure (20).

Adult-onset HBV-related MGN may have a different natural history. In contrast to reports in children, a study (16) of 21 Hong Kong adult patients found that only one of the five patients treated with interferon experienced remission. Moreover, in that study, no untreated patients experienced spontaneous remission. The study also found a negative correlation between the extent of membrane deposits and the chance of complete remission.

The results of treatment of HBV-related MGN have been variable. Although there are controlled trials of corticosteroids in adults with idiopathic MGN, there have been no controlled studies in HBV-related MGN. Anecdotal and retrospective studies show no clear benefit of corticosteroids over symptomatic treatment with diuretics $(28,29)$. Lai et al $(28)$ studied eight adult patients with HBV-related MGN, of which seven of eight had nephrotic syndrome. A six-month course of corticosteroids was associated with partial resolution of nephrotic syndrome in three of seven patients. Two of seven historical controls treated with diuretics alone experienced a spontaneous remission. In another study by Wyszynska et al (29), immunosuppressive therapy did not alter the course of HBVrelated MGN in children. Furthermore, short-term or prolonged steroid use may lead to an increase in viral replication and a subsequent worsening of hepatic function $(28,30)$. There is a single case report (31) of liver transplantation resulting in resolution of HBV-related MGN in a 15-year-old girl.

Antiviral therapy for HBV-related MGN was first attempted as early as 1985 (32). Interferon and adenine arabinoside have both been used with variable success $(33,34)$. Over 50 patients treated with interferon have been reported in the literature $(20,34-42)$. In one case series (37) of 15 patients treated with interferon, eight patients had a virological response defined by loss of HBeAg and HBV DNA. Seven of these eight patients had improved renal function with decreased proteinuria. In contrast, none of the patients without seroconversion had an improvement in proteinuria and one patient went on to require dialysis (37). Lin (38) reported the only controlled trial of interferon in 1995. Forty patients were randomly assigned to treatment with interferon three times weekly for 12 months or supportive care. Of the 20 interferon-treated patients, $60 \%$ had $\mathrm{HBeAg}$ seroconversion, $40 \%$ had $\mathrm{HBs} A g$ seroconversion and all interferon-treated patients had resolution of proteinuria. Conversely, none of the untreated patients had $\mathrm{HBeAg}$ or HBsAg seroconversion and all continued to have significant proteinuria. The seroconversion rates in this study were much higher than those found in a meta-analysis of interferon trials (43), in which pooled $\mathrm{HBeAg}$ loss was seen in $33 \%$ and HBsAg seroconversion occurred in 7.8\%. Although this observation is based on a small number of patients, this suggests that HBV patients with associated renal disease may be more responsive to interferon-based therapy.

Lamivudine is a pyrimidine nucleoside analogue that interrupts hepatitis B viral replication. The drug is well-tolerated and usually results in a significant reduction of HBV DNA levels. However, HBeAg seroconversion is achieved in only $16 \%$ to $18 \%$ of patients after one year of therapy (44). Extended durations of lamivudine therapy will improve seroconversion rates but comes at a cost of higher rates of YMDD mutants that confer resistance to lamivudine (44).

To date, the use of lamivudine to specifically treat HBVrelated MGN has mainly been reported in the pediatric literature $(1,2)$. In one study $(1)$, a six-year-old boy experienced remission of HBV-associated MGN after five months of lamivudine. In a second report (2), a five-year-old girl experienced remission after three months of lamivudine. In the single report (3) detailing the use of lamivudine in an adult, a 41-year-old man experienced remission of his HBV-associated MGN with the combined use of intravenous methylprednisolone and cyclophosphamide, rendering some doubt as to which therapy proved to be beneficial.

The exact impact of lamivudine in our two patients is unclear. The first patient had a prompt $\mathrm{HBeAg}$ seroconversion, which resulted in an improvement in his nephrotic syndrome, although he continues to have mild proteinuria. With the appearance of a precore mutant (HBeAg-negative, HBV DNA-positive), his nephrotic syndrome did not deteriorate and this recurrent viremia was brought under control with a second course of lamivudine. However, the patient has been on enalapril since his presentation. ACE inhibition has been shown to result in a significant reduction in proteinuria and preservation of renal function in nondiabetic patients with glomerular diseases (45). Therefore, we cannot exclude the possibility that the improvement in his nephrotic syndrome was related to the use of an ACE inhibitor and not due to the suppression of his HBV DNA by lamivudine.

The second patient had no virological response to 15 months of lamivudine therapy. In spite of ongoing HBV viremia, her nephrotic syndrome slowly resolved over the subsequent two years. It should be noted that this patient was not hypertensive and at no point were ACE inhibitors used. Slow improvement in nephrotic syndrome has also been noted in patients with a response to interferon (37), but our patient only received five doses of interferon. Spontaneous remission of HBV-associated 
glomerulopathy in adults is apparently quite rare, although it did occur in two of seven historical controls treated with diuretics alone in the study by Lai et al (28). Although we cannot exclude the possibility that lamivudine may have influenced the natural history of her nephrotic syndrome, despite the lack of virological response, it appears more likely that she entered a spontaneous remission.

Regardless, in our experience, lamivudine was well-tolerated in both patients and improvement in the nephrotic syndrome was noted in both subjects. Therefore, lamivudine should be considered as an alternative to interferon for patients with HBVrelated glomerulopathy. HBV patients with glomerulopathy may have a different natural history, with higher seroconversion rates

\section{REFERENCES}

1. Connor FL, Rosenberg AR, Kennedy SE, Bohane TD. HBV associated nephrotic syndrome: Resolution with oral lamivudine. Arch Dis Child 2003;88:446-9.

2. Filler G, Feber J, Weiler G, Le Saux N. Another case of HBV associated membranous glomerulonephritis resolving on lamivudine. Arch Dis Child 2003;88:460.

3. Balal M, Seyrek N, Karayayali I, Paydas S, Gonlusen G. Use of immunosuppressive drugs and lamivudine in a patient with nephrotic syndrome, severe renal failure, and HBV cirrhosis: Case report. Adv Ther 2003; 20:191-4.

4. Combes B, Shorey J, Barrera A, et al. Glomerulonephritis with deposition of Australia antigen-antibody complexes in glomerular basement membrane. Lancet 1971;2:234-7.

5. Hirschel BJ, Benusiglio LN, Favre H, et al. Glomerulonephritis associated with hepatitis B. Report of a case and review of the literature. Clin Nephrol 1977:404-9.

6. Iida H, Izumino K, Asaka M, et al. Membranoproliferative glomerulonephritis associated with chronic hepatitis B in adults: Pathogenetic role of HBsAg. Am J Nephrol 1987;7:319-24.

7. Myers BD, Griffel B, Naveh D, Jankielowiiz T, Klajman A. Membrano-proliferative glomerulonephritis associated with persistent viral hepatitis. Am J Clin Pathol 1973;60:222-8.

8. Stratta P, Camussi G, Ragni R, Vercellone A. Hepatitis-B antigenaemia associated with active chronic hepatitis and mesangioproliferative glomerulonephritis. Lancet 1975;2:179.

9. Bhimma R, Coovadia HM. Hepatitis B virus-associated nephropathy. Am J Nephrol 2004;24:198-211.

10. Michalak T. Immune complexes of hepatitis B surface antigen in the pathogenesis of periarteritis nodosa. A study of seven necropsy cases. Am J Pathol 1978;90:619-32.

11. Lai K, Lai F, Lo S, Ho C, Chan K. IgA nephropathy associated with hepatitis B virus antigenemia. Nephron 1987;47:141-3.

12. Lai K, Lai F, Tam J, Vallance-Owen J. Strong association between IgA nephropathy and hepatitis B surface antigenemia in endemic areas. Clin Nephrol 1988;29:229-34.

13. Lai K, Lai F, Tam J. IgA nephropathy associated with chronic hepatitis $B$ virus infection in adults: The pathogenetic role of HBsAg. J Pathol 1989;157:321-7.

14. Kleinknecht C, Levy M, Peix A, Broyer M, Courtecuisse V. Membranous glomerulonephritis and hepatitis B surface antigen in children. J Pediatr 1979;95:946-52.

15. Yoshikawa N, Ito H, Yamada Y, et al. Membranous glomerulonephritis associated with hepatitis B antigen in children: A comparison with idiopathic membranous glomerulonephritis. Clin Nephrol 1985;23:28-34.

16. Lai K, Li P, Lui S, et al. Membranous nephropathy related to hepatitis B virus in adults. N Engl J Med 1991;324:1457-63.

17. Hsu H, Lin G, Chang M, Chen C. Association of hepatitis B surface (HBs) antigenemia and membranous nephropathy in children in Taiwan. Clin Nephrol 1983;20:121-9.

18. Wiggelinkhuizen J, Sinclair-Smith C, Stannard L, Smuts H. Hepatitis B virus associated membranous glomerulonephritis. Arch Dis Child 1983;58:488-96.

19. Johnson RJ, Couser WG. Hepatitis B infection and renal disease: Clinical, immunopathogenetic and therapeutic considerations. Kidney Int 1990;37:663-76. when treated with interferon (38). Further studies are required to delineate the response rates and efficacy of lamivudine in this subgroup of HBV patients.

\section{CONCLUSION}

Lamivudine appears to be a potentially safe and effective means of treating adults with glomerular disease associated with HBV. Lamivudine should be considered a potential alternative to interferon for HBV patients with glomerulopathy who are intolerant of or unwilling to take interferon-based therapy. Whether a patient with HBV-related MGN will be more responsive to lamivudine, as was suggested with the use of interferon, deserves further study.

20. Wong SN, Yu EC, Chan KW. Hepatitis B virus associated membranous glomerulonephritis in children-experience in Hong Kong. Clin Nephrol 1993;40:142-7.

21. Brzosko WJ, Krawczynski K, Nazarewicz T, Morzycka M, Nowoslawski A. Glomerulonephritis associated with hepatitis-B surface antigen immune complexes in children. Lancet 1974;2:477-82.

22. Maggiore Q, Bartolomeo F, L'Abbate A, Misefari V. HBsAg glomerular deposits in glomerulonephritis: Fact or artifact? Kidney Int 1981;19:579-86.

23. Kohler PF, Cronin RE, Hammond WS, Olin D, Carr RI. Chronic membranous glomerulonephritis caused by hepatitis B antigenantibody immune complexes. Ann Intern Med 1974;81:448-51.

24. Furuse A, Hattori S, Terashima T, Karashima S, Matsuda I. Circulating immune complex in glomerulopathy associated with hepatitis B virus infection. Nephron 1982;31:212-8.

25. Gregorek H, Jung A, Grabowska B, Madalinski K. Isolation and partial characterization of circulating immune complexes in sera of children with HBV-mediated glomerulonephritis. Arch Immunol Ther Exp (Warsz) 1991;39:519-27.

26. He X, Fang L, Zhang Y, Sheng F, Zhang X, Guo M. In situ hybridization of hepatitis B DNA in hepatitis B-associated glomerulonephritis. Pediatr Nephrol 1998;12:117-20.

27. Lai KN, Ho RT, Tam JS, Lai FM. Detection of hepatitis B virus DNA and RNA in kidneys of HBV related glomerulonephritis. Kidney Int 1996;50:1965-77.

28. Lai K, Tam J, Lin H, Lai F. The therapeutic dilemma of the usage of corticosteroid in patients with membranous nephropathy and persistent hepatitis B virus surface antigenaemia. Nephron $1990 ; 54: 12-7$.

29. Wyszynska T, Jung H, Madalinski K, Morzycka M. Hepatitis B mediated glomerulonephritis in children. Int J Pediatr Nephrol 1984;5:147-58.

30. Scullard G, Smith C, Merigan T, Robinson W, Gregory P. Effects of immunosuppressive therapy on viral markers in chronic active hepatitis B. Gastroenterology 1981;81:987-91.

31. Quan A, Portale A, Foster S, Lavine J. Resolution of hepatitis B virus-related membranoproliferative glomerulonephritis after orthotopic liver transplantation. Pediatr Nephrol 1995;9:599-602.

32. Esteban R, Buti M, Valles M, Allende H, Guardia J. Hepatitis Bassociated membranous glomerulonephritis treated with adenine arabinoside monophosphate. Hepatology 1986;6:762-3.

33. Lin C, Lo S. Treatment of hepatitis B virus-associated membranous nephropathy with adenine arabinoside and thymic extract. Kidney Int 1991;39:301-6.

34. Shapiro R, Steinbrecher U, Magil A. Remission of nephrotic syndrome of HBV-associated membranous glomerulopathy following treatment with interferon. Am J Nephrol 1995;15:343-7.

35. Garcia G, Scullard G, Smith C, et al. Preliminary observation of hepatitis B-associated membranous glomerulonephritis treated with leukocyte interferon. Hepatology 1985;5:317-20.

36. Chung DR, Yang WS, Kim SB, et al. Treatment of hepatitis B virus associated glomerulonephritis with recombinant human alpha interferon. Am J Nephrol 1997;17:112-7.

37. Conjeevaram H, Hoofnagle J, Austin H, Park Y, Fried M, Di Bisceglie A. Long-term outcome of hepatitis B virus-related 
glomerulonephritis after therapy with interferon alfa. Gastroenterology 1995;109:540-6.

38. Lin CY. Treatment of hepatitis B virus-associated membranous nephropathy with recombinant alpha-interferon. Kidney Int 1995:47:225-30

39. Wong SN, Yu EC, Lok AS, Chan KW, Lau YL. Interferon treatment for hepatitis B-associated membranous glomerulonephritis in two Chinese children. Pediatr Nephrol 1992;6:417-20.

40. Jonas M, Ragin L, Silva M. Membranous glomerulonephritis and chronic persistent hepatitis B in a child: Treatment with recombinant interferon alfa. J Pediatr 1991;119:818-20.

41. Lisker-Melman M, Webb D, Di Bisceglie AM, et al. Glomerulonephritis caused by chronic hepatitis B virus infection: Treatment with recombinant human alpha-interferon. Ann Intern Med 1989;111:479-83.
42. Mizushima N, Kanai K, Matsuda H, et al. Improvement of proteinuria in a case of hepatitis B-associated glomerulonephritis after treatment with interferon. Gastroenterology 1987;92:524-6

43. Wong DK, Cheung AM, O'Rourke K, Naylor CD, Detsky AS, Heathcote J. Effect of alpha-interferon treatment in patients with hepatitis B e antigen-positive chronic hepatitis B. A meta-analysis. Ann Intern Med 1993;119:312-23.

44. Lok AS, Heathcote EJ, Hoofnagle JH. Management of hepatitis B: 2000-summary of a workshop. Gastroenterology 2001;120:1828-53.

45. The GISEN Group (Gruppo Italiano di Studi Epidemiologici in Nefrologia). Randomised placebo-controlled trial of effect of ramipril on decline in glomerular filtration rate and risk of terminal renal failure in proteinuric, non-diabetic nephropathy. The GISEN Group (Gruppo Italiano di Studi Epidemiologici in Nefrologia). Lancet 1997;349:1857-63. 


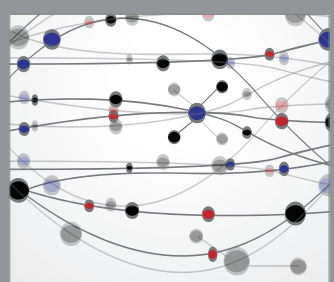

The Scientific World Journal
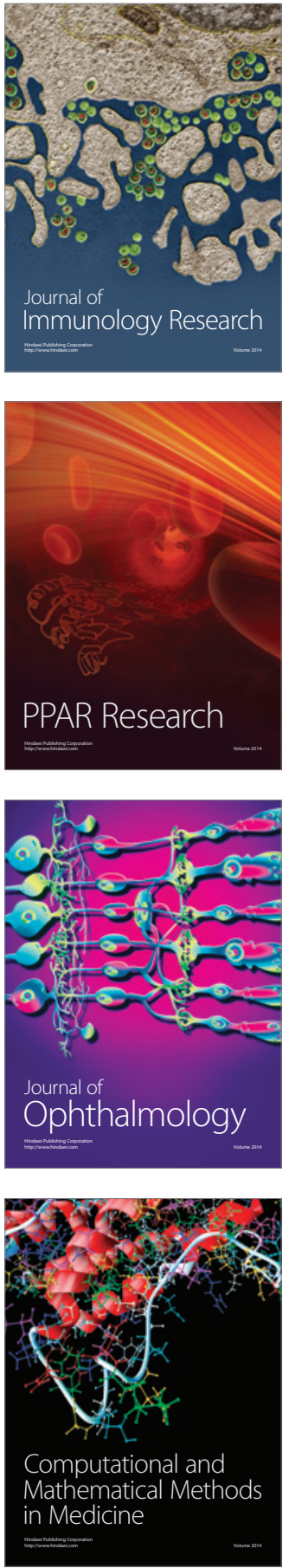

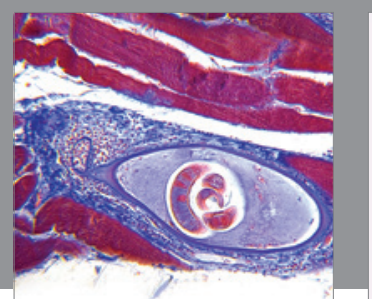

Gastroenterology Research and Practice

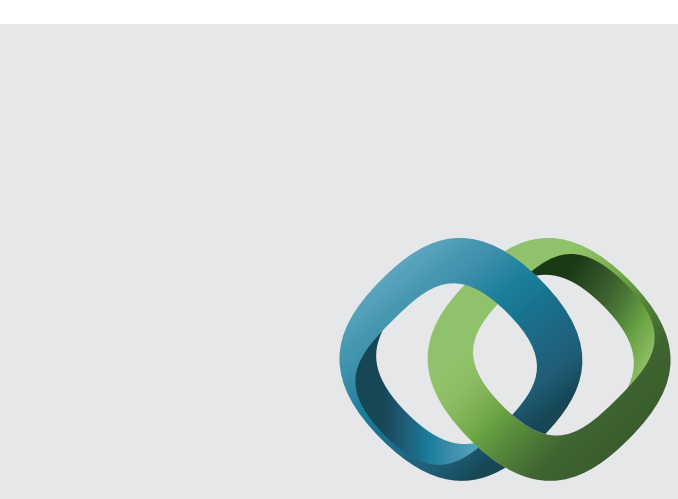

\section{Hindawi}

Submit your manuscripts at

http://www.hindawi.com
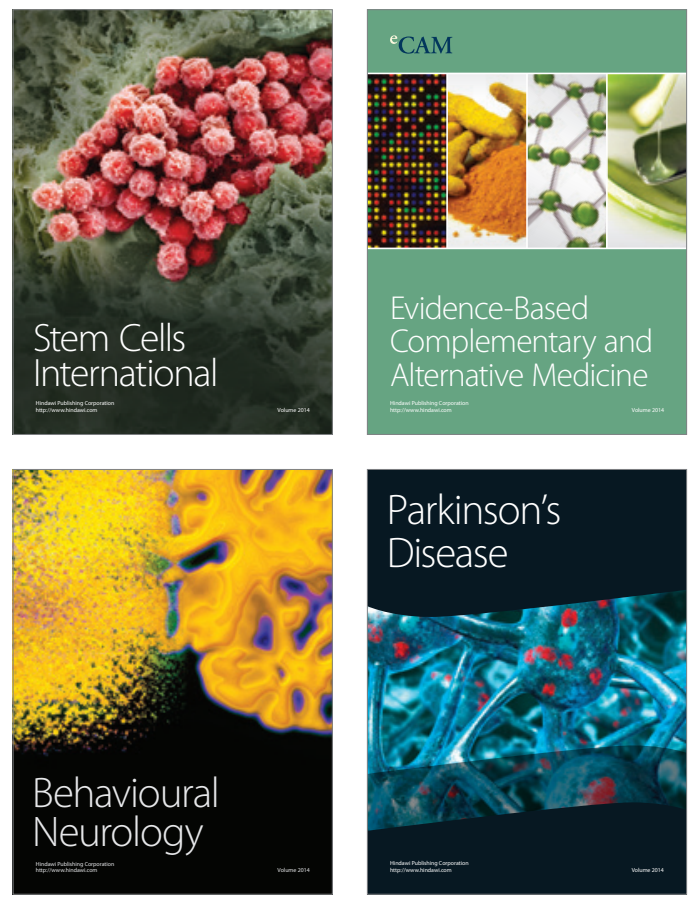
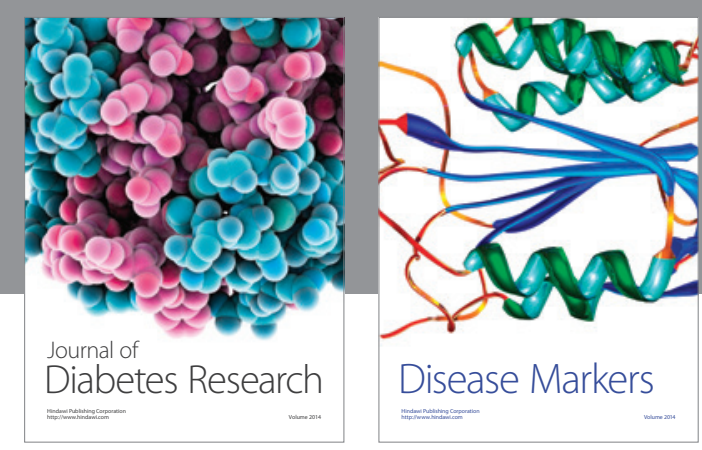

Disease Markers
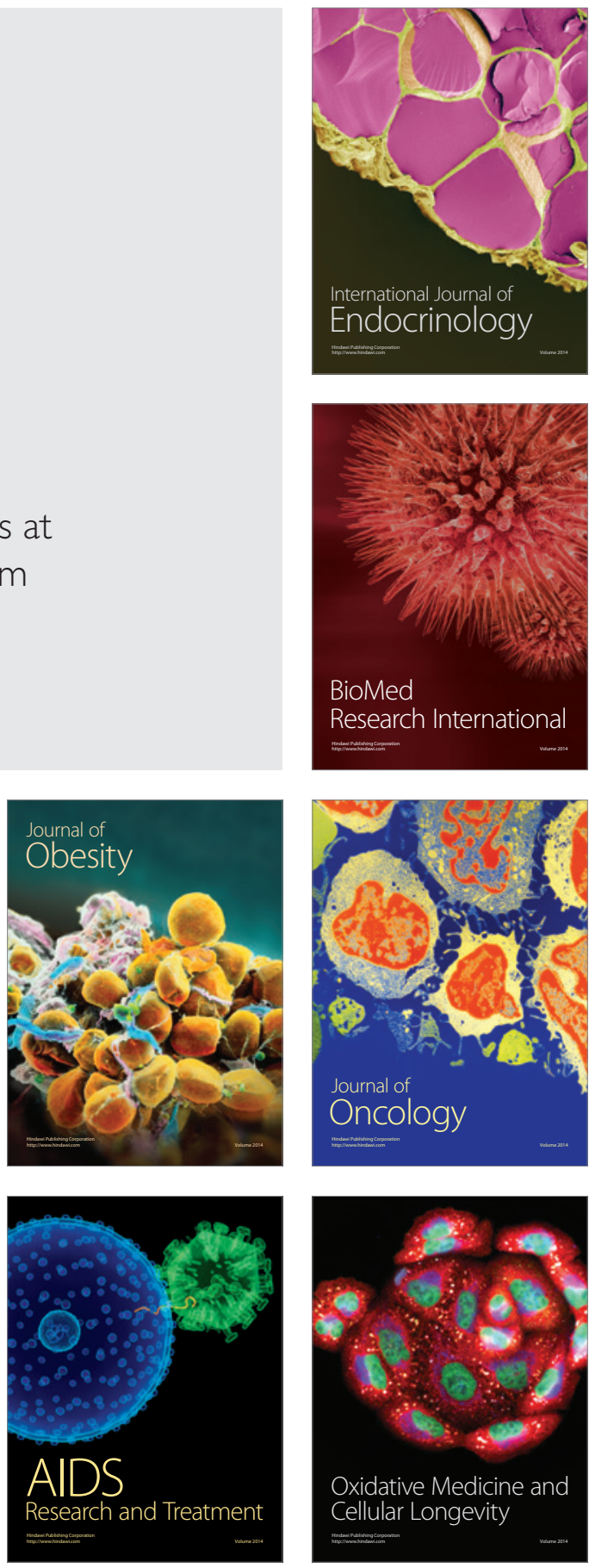